\title{
O imaginário e o poético nas obras de Miguel Ángel Asturias e Octavio Paz
}

\author{
The imaginary and the poetic in the works of Miguel Angel \\ Asturias and Octavio Paz
}

Mariluci Guberman

\section{UFRJ mariluciufrj@yahoo.com.br}

RESUMO: O diálogo da modernidade com a tradição na América Latina e a resistência da memória, aliada à tradição e ao imaginário dos povos desse continente. A história e o imaginário dos universos dos maias e dos astecas por meio da linguagem inovadora de Miguel Ángel Asturias (Guatemala) e Octavio Paz (México). A realidade filtrada pela linguagem mágica de Asturias: elementos mágicos que pertencem à suprarrealidade da Guatemala. Surrealismo ou realismo mágico? Octavio Paz e o pensamento dos nahuas (astecas). O movimento cíclico das imagens no poema paciano, "Piedra de sol", e o tempo petrificado e despetrificado no instante poético da criação literária, a imaginação do poeta feita poesia. As raízes mexicanas no poema de Paz, "Mariposa de obsidiana", símbolo do movimento e memória de um povo: recordação do passado de trevas e projeção de um futuro de luz.

Palavras-chave: Modernidade e tradição. Ruptura. Memória. História. Imagem e imaginário.

ABSTRACT: The dialog of the modernity with the tradition in the Latin America and the resistance of the memory, allied to the tradition and to an imaginary one of the people of this continent. The history and the imaginary of the universes of the maias and of the aztecs through the innovatory language of Miguel Ángel Asturias (Guatemala) and Octavio Paz (Mexico). The reality filtered by the magic language of Asturias: magic elements that belong to the supra-reality of Guatemala. Surrealism or magic realism? Octavio Paz and the thought of the (aztec) nahuas. The cyclical movement of the images in the poem paciano, "Piedra of sun", and the petrified time and despetrificado in the poetic instant of the literary creation, the imagination of the poet done poetry. The mexican roots in the Peace poem, "Moth of obsidiana", symbol of the 
movement and memory of people: memory of the past of darkness and projection of a future of light.

Keywords: Modernity and tradition. Break. Memory. History. Image and imaginary.

Como a concepção de antigo e moderno está relacionada com a ideia de tempo, ao se espelhar nos antigos, criava-se uma sucessão temporal, degenerativa de um tempo primordial e perfeito. No século XIX, em oposição a essa continuidade, surge a modernidade, na qual o presente é único, não pretendendo repetir o passado e revelando um mundo infinito, repleto de inovações e fadado a desaparecer para sempre.

As modernas ideias desse século apoiavam-se na expressão "derreter os sólidos" do Manifesto comunista como, por exemplo, nos estudos básicos de Marshall Berman (1986) e de Zygmunt Bauman (2001). Se a intenção de "derreter os sólidos", de certa maneira, clamava pela profanação do sagrado; conforme Bauman (2001, p. 9), de outra, clamava pelo repúdio e destronamento do passado, da tradição. De acordo com Octavio Paz (1989, p. 17-18), "Se tradição significa continuidade do passado no presente, como pode se falar de uma tradição sem passado e que consiste na exaltação daquilo que o nega: a pura atualidade?” A modernidade não impede a tradição. Octavio $\operatorname{Paz}$ (1989, p. 21), ao abordar a "literatura de fundação", afirma que "a literatura hispano-americana é regresso e busca de uma tradição". O escritor latino-americano ao buscar essa tradição "a inventa", mas descobrimento e invenção não são os melhores termos para o ato de criação, e sim "vontade de encarnação, literatura de fundação”. O escritor, então, ao instaurar o diálogo da modernidade com a tradição, cria sua obra repleta de magia. 
Enquanto na Europa predominou o termo modernidade, na América Latina preponderou o termo vanguarda. Este último não era apreciado por Charles Baudelaire (1821-1867). De acordo com Octavio Paz (1994), o escritor francês não gostava do termo avantgarde por suas ressonâncias militares, pois significa "deslocamento de uma força que vai para frente do restante em ação ou ataque". E, quando Baudelaire comparava a arte de seu tempo com a de outras épocas, referia-se ao moderno ou à modernidade.

$\mathrm{Na}$ modernidade, iniciada com as máquinas e os meios de comunicação, principais impulsores do desenvolvimento da sociedade capitalista, conforme Berman (1986, p. 19),

[...] a primeira coisa que observaremos será a nova paisagem, altamente desenvolvida, diferenciada $e$ dinâmica, na qual tem lugar a experiência moderna. Tratase de uma paisagem de engenhos a vapor, fábricas automatizadas, ferrovias, amplas novas zonas industriais; prolificas cidades que cresceram do dia para a noite, quase sempre com aterradoras consequências para o ser humano; jornais diários, telégrafos, telefones e outros instrumentos de media, que se comunicam em escala cada vez maior; [...].

O movimento, a máquina, a velocidade quase não permitiram aos artistas se deterem no passado. Ao se derreter o que havia se solidificado, novos mecanismos de poder surgiram, como afirma Bauman (2001, p. 18): "a fuga, a astúcia, o desvio e a hesitação, a efetiva rejeição de qualquer confinamento territorial". Essa rejeição de confinamento foi denominada "dissolução das fronteiras" pela autora deste estudo (GUBERMAN, 1997, p. 97). 
Com o advento da modernidade, a memória (BENJAMIN, p. 1985) passou a ser um verdadeiro "agente de resistência" (CANTON, 2009, p. 21), com a tradição (BAUMAN, 2010 e 2012) e o imaginário (DURAND, 1998), colaborando com a preservação do imaginário dos povos que habitaram e/ou habitam o continente latino-americano. Para Gilbert Durand (1998, p. 6), o imaginário é um "museu [...] de todas as imagens passadas, possíveis, produzidas e a serem produzidas". Trata-se de um conceito adequado para abordar a imagística desse continente, que contrasta com a visão realista de alguns estudiosos e viajantes. As imagens, para Justo Villafañe (2002, p. 30), “[...] surgem do nível do imaginário, mantêm com a realidade nexos, que às vezes são mais sólidos do que em uma primeira leitura se pudera supor".

Na modernidade o indivíduo deixou de ser a unidade homem e, em nome do progresso, cada vez mais se afastou da natureza e voltou o olhar para a cidade, centro de todos os focos da modernidade. $\mathrm{O}$ processo acelerado de industrialização tratou os homens como máquinas, como se pode observar no romance de Miguel Ángel Asturias, Viento fuerte ${ }^{1}$, em que se percebe a febre da empresa norteamericana United Fruit Co. na exploração frutífera da Guatemala, levando os habitantes de origem maia a abandonar o cultivo do milho (planta sagrada dessa civilização) para cultivar a banana em busca da riqueza, e provocando, em Viento fuerte (1950, p. 28), o surgimento do homem-máquina: “[...] llegaba la organización humana, se puede decir, porque a partir de allí con otros hombres empezaba la maquinaria ciega, implacable, que todo lo convertía a cifras en sus libros, inalterable, cronométrica, precisa".

Todas essas transformações econômicas e sociais traçam um novo perfil do povo guatemalteco, um aparente equilíbrio que não 
permite a essa gente um exame de si mesmo, conduzindo-a a solidão, pois somente então se atreve a ser, conforme Octavio Paz em $O$ labirinto da solidão (1987, p. 64): "Esclavos, siervos y razas sometidas se presentan siempre recubiertos por una máscara, sonriente $o$ adusta [...]. Para salir de sí mismo el siervo necesita saltar barreras, embriagarse, olvidar su condición. Vivir a solas, sin testigos. Solamente en la soledad se atreve a ser".

Neste estudo, selecionaram-se as obras de dois escritores latinoamericanos, o poeta e romancista guatemalteco, (I) Miguel Ángel Asturias (1899-1974), e o poeta e ensaísta mexicano, (II) Octavio Paz (1914-1998), que se preocuparam, como muitos, em revelar, na modernidade, a memória dos povos que habitaram a América Latina. Embora suas produções literárias tenham um aporte histórico, elas ganham magia e lirismo com o imaginário dos universos dos maias e dos astecas, plasmado por Asturias e Paz com uma linguagem inovadora.

\section{I}

A primeira manifestação poética de Miguel Ángel Asturias (Prêmio Nobel de Literatura em 1967) foi por ocasião do terremoto de 1917 que destruiu a Guatemala. Asturias, ao presenciar as injustiças sociais e a retirada dos escombros para a reconstrução da Capital, se rebela e escreve Toque de Ánimas e Los mendigos políticos (1922). Este conto será o gérmen de El Señor Presidente (1946). Entre 1918 e 1954, Miguel Ángel Asturias escreveu diversos poemas, que integram Sien de alondra. O escritor guatemalteco publicou em revistas outros poemas, como "Bolívar" (1955), "Nombre custodio e imagen pasajera" (1959), "Sonetos de Italia" 
(1965). Também é autor do poema em prosa Clarivigilia primaveral (1965), além de ensaios e peças teatrais.

Asturias conviveu com o mundo mágico em sua infância, entre 4 e 7 anos, quando seu pai sofreu perseguições políticas e foi obrigado a viver com os índios maias da família de sua mãe, conforme palavras do próprio escritor:

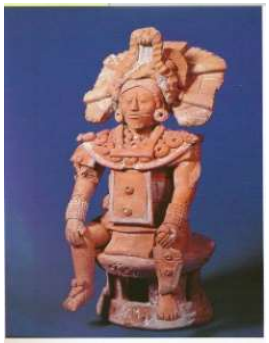

Mi abuelo me dejaba en los ranchos y allá había indiecitos pequeños como yo o un poco más grandes, y con ellos empecé a jugar. El juego de ellos, principalmente, era hacer figuritas de barro, un barro un poco rojo, del color de aquellas tierras. Yo con esto, al mismo tiempo que aprendia las letras, iba también aprendiendo a hacer estas figuras, que eran un poco el trasunto de la mentalidad de ellos, de sus creencias. ${ }^{2}$

A realidade filtrada pela linguagem mágica é o recurso empregado por Miguel Ángel Asturias para personalizar os nativos de sua terra. Mais que um recurso, é a própria essência do povo guatemalteco que vem à tona: mitos, tradições, associados à história da Guatemala. São elementos mágicos que pertencem à suprarrealidade. O autor da "trilogia bananeira", ao apoiar-se na suprarrealidade, remete o leitor ao surrealismo, entretanto, a linguagem mágica em que ele se apoia pertence também à realidade guatemalteca. Porém, deve-se questionar se é possível caracterizar a obra de Miguel Ángel Asturias como surrealista, considerando que o autor participou do movimento na França, junto com Robert 
Desnos, André Breton, Louis Aragon, Paul Éluard, o inglês Eugene Jolas e a norte-americana Gertrude Stein.

André Breton, ao lançar em 1924 o Manifesto do surrealismo, o ressaltou como "Anti-realismo, anti-naturalismo, negação e também execração absoluta do real como matéria e base da arte" (BRETON, 1985). O surrealismo propõe uma escritura automática para a qual pede abdicação da razão no processo artístico, deixando correr livremente o inconsciente. É a exaltação deste, do sonho, do ilógico, do absurdo, mas Miguel Ángel Asturias qualifica o surrealismo francês como "muito intelectual" e declara (ASTURIAS, 1975, p. 125) que em seus livros “... el surrealismo adquiere un carácter mágico y diferente por completo. El no trata de una actitud intelectual, pero de una actitud vital, existencial. Es la actitud del indio que, con su mentalidad primitiva e infantil, mezcla lo real y lo imaginario, lo real y el sueño".

Na América Hispânica, o homem convive com uma realidade mágica que faz parte de seu passado indígena ou de origem africana. Não é necessário buscar no sonho ou no automatismo psíquico, nem tampouco afastar-se da realidade, deixando levar-se pelas manifestações do inconsciente, porque a literatura hispanoamericana emerge de todos estes fatores sem a criação de uma suprarrealidade. Ela é a própria realidade, o próprio referencial. Conforme Asturias (1967, p. 13), “... el surrealismo de mis libros corresponde un poco a la mentalidad indígena, mágica y primitiva, a la mentalidad de esta gente que está siempre entre lo real y lo que se inventa. Y creo que esto es lo que forma el eje principal de mi pretendido ${ }^{3}$ surrealismo". 
Esta percepção mágica do autor sobre a realidade guatemalteca se deve ao contraste da educação abstrata ocidental de Asturias com a educação material dos indígenas:

En Salamá tuve contacto con los indígenas, pero tuve contacto también con las piedras, con el barro, con los telares; estuve en contacto con los objetos industriales de la vida más elemental, si se quiere, pero vida al fin, vida de objetos que están en función de utilidad humana. Objetos de los que no se hacía comercio, sino que se producían junto los que podían servir. ${ }^{4}$

A percepção aguçada em sua infância possibilita a Miguel Ángel Asturias a passagem tanto para o real histórico quanto para o real mágico. Realidades distintas que, na "trilogia bananeira" e em outras obras do autor guatemalteco, se fundem em uma leitura simultânea do realismo mágico, quando já não se distingue uma realidade da outra. Deve-se ressaltar que o realismo mágico é uma concepção de um fenômeno coletivo, religioso e histórico que, em nível continental, representa a necessidade de estabelecer "uma profissão de fé" sob os mesmos princípios de "ruptura" do movimento literário europeu. Nos textos indígenas encontra-se a suprarrealidade que buscavam os seguidores de André Breton, conforme declaração do próprio Asturias (1963):

Mi realismo es "mágico" porque él revela un poco del sueño como lo conciben los surrealistas. Tal como lo conciben también los Mayas en sus textos sagrados. Leyendo estos últimos yo me ha dado cuenta que existe una realidad papable sobre cual se injerta una otra realidad, creada por la imaginación, y que se envuelve de tantos detalles que ella llega a ser tan "real" como la otra. Toda 
mi obra se desenvuelve entre estas dos realidades: la una social, política, popular, con personajes que hablan como habla el pueblo guatemalteco; la otra imaginaria, que les encierra en una especie de ambiente y de paisaje de sueño. ${ }^{5}$

Com o apoio dos mitos maias, Miguel Ángel Asturias rompe com as "estruturas mentais da tradição espanhola", sem a preocupação de absorver temas regionais, porque seu principal objetivo é a linguagem. É um dos primeiros escritores a perceber o vasto potencial psíquico da linguagem oral. Por meio desta pode expressar as realizações mais complexas da existência espiritual de seu povo. Esta preocupação de Asturias (1973, p. 257) obteve êxito por causa de sua experiência entre os indígenas:

El realismo mágico tiene seguramente una relación directa con la mentalidad original del indígena. El indígena piensa en imágenes; no ve como las cosas se procesan, las lleva siempre para otras dimensiones en las cuales vemos desaparecer lo real y surgir el sueño, en donde los sueños se transforman en realidad tangible y visible.

O uso da imagem por Miguel Ángel Asturias, seja surrealista, seja uma forma mágica de conceber o real, encontra explicação em suas próprias palavras (ASTURIAS, 1968, p. 288):

Otro idioma va a regar sus destellos sobre sonidos y palabras. El idioma de las imágenes. Nuestras novelas aparecen escritas no sólo con palabras sino con imágenes. No son pocos los que leyendo nuestras novelas las ven cinematográficamente. $Y$ no porque se persiga una dramática afirmación de independencia sino porque nuestros novelistas están empeñados en universalizar la 
voz de sus pueblos, con un idioma rico en sonidos, rico en fabulaciones y rico en imágenes.

Para Miguel Ángel Asturias, a fundamentação da imagem está na magia, pois é vista como "otra luz iluminando el universo de dentro afuera". Esta luz seria a clarividência, ou seja, a inspiração que permite ao poeta ver as coisas em seu ser mágico, porque para ele os poetas se fundem com o ser dos objetos, é o "clarivigilante", "ni despierto ni dormido", de Clarivigilia primaveral (ASTURIAS, 1965, p. 68):

El vuelvo inmóvil de la poesía y sus desdoblamientos en canto ritual, danza guerrera, juego de palabras, coloquio de corazones endiosados es nuestro secreto. Oír brotar almácigas de sílabas y transplantarlas de las salivaciones a la estrofa dorada, nuestro oficio de pensadores con música. Conocemos el pulso de las lluvias flagelantes en el dibujo calendárico y la caligrafía colorida, polícroma, de símbolos y adivinaciones astrológicas; pero postergadas por el Mágico del Canto, no pasamos de ser hablacadáveres de lenguas perforadas con flechas de metáforas.

Para análise da obra de Miguel Ángel Asturias, selecionaram-se para este estudo os poemas "Tecún-Umán” e “Tiempo y muerte em Copán” (ASTURIAS, 1975).

\section{Tecún-Umán}

No poema “Tecún-Umán”, publicado no México em 1945, é fundamental para sua análise o complexo sistema mitológico maia, 
substrato significativo na produção de Miguel Ángel Asturias, a fim de revelar a interação entre os elementos constituintes do mundo mitológico maia e a obra asturiana. No livro sagrado dos maias, o Popol-Vuh, encontram-se os deuses criadores como a Serpente Emplumada ${ }^{6}$. A Grande serpente com suas sinuosidades foi a que deu forma à Terra no ato de Criação.

Nas representações plásticas da cultura maia, visualiza-se uma figura com uma perna normal e outra transformada em serpente, o que leva a associá-la à Serpente Emplumada que possui o olho em forma de T, significando IK (etm. vento). Portanto, também é “deus do vento". Outra correlação é o grande tambor sagrado da Serpente emplumada, ao qual se atribui a voz do Furacão (Huracán). Este tambor surge no poema "Tecún-Umán”, quando o sujeito do poema estabelece a associação entre "Tecún-Umán, el de los atabales" e "ruido tributario de la tempestad", plasmando a ideia do tambor como um instrumento capaz de desdobrar o golpe do trovão em eco, intensificando-o na obra a partir de um meio fonomelódico, a onomatopeia, que imita o ruído do tambor:

\author{
Tecún-Umán, el de los atabales, \\ ruido tributario de la tempestad \\ en seco de los tamborones, cuero \\ de tamborón que lleva cuero, cuero \\ adentro, cuero en medio, cuero afuera, \\ cuero de tamborón, bón, bón, borón, bón, \\ bón, bón, borón, bón, bón, bón, borón, bón, \\ bón, borón, bón, bón, bón, borón, bón, bón, \\ pepitoria de trueno que golpea [...]
}

Tecún-Umán foi um guerreiro, que em luta com o conquistador espanhol Pedro de Alvarado foi protegido por Quetzal, pássaro 
sagrado dos maias. A lenda conta que o guerreiro, devido a uma flechada, mancha com sangue o peito do Quetzal, que não cantou mais e somente voltará a fazê-lo quando os nativos guatemaltecos puderem resgatar a liberdade perdida. $\mathrm{O}$ pássaro sagrado tem sua imagem poética retratada em Leyendas de Guatemala, também de Asturias (1985, p.145): "Es una esmeralda del tamaño de una paloma que parece arrastar un arco-iris en la cola de más de un metro. $\mathrm{Su}$ plumaje verde posee todos los cambiantes del tornasol, y se diría, pintado sobre un fondo de oro, como los mosaicos bizantinos".

Neste estudo deve-se observar o aspecto fônico do poema “Tecún-Umán”, já que o escritor guatemalteco lança mão de jogos fonológicos para intensificar a expressividade poética. Convém lembrar que todo recurso fonético pressupõe uma conotação fonomelódica, função, por exemplo, da reiteração, que se encontra ao longo do poema (ASTURIAS, 1975, p. 134):

Tecún-Umán, el de las plumas verdes,
el de las largas plumas verdes, verdes,
el de las plumas verdes, verdes, verdes,
verdes, verdes, Quetzal de varios frentes.

Miguel Ángel Asturias se apoia na alteração da palavra como recurso fonossemântico. Nos últimos versos (ASTURIAS, 1975, p. 136), "Ya no es el tún! [...] / Ahora es el tán-tán de las campanas! [...]", o sujeito do poema ao substituir o ruído do tambor pelo das campanas expõe a dominação religiosa que tomou conta da cultura maia.

Também a aglutinação do vocábulo "Quetzal” a "umán” ou a "tecún" formando neologismos como "Quetzalumán" ou “Quetzaltecún”, além de converter o guerreiro em deus, realiza um 
reforço semântico que sacraliza o herói maia perante os dominadores, perpetuando poeticamente a civilização maia.

\section{Tiempo y muerte en Copán}

No poema "Tiempo y muerte en Copán”, escrito entre 1954 e 1955, Miguel Ángel Asturias trata da grande cidade maia de Copán, hoje sítio arqueológico de visitação pública situado em Honduras. Copán inegavelmente é um dos conjuntos de ruínas maias mais bonito do período Clássico (300 a 900 de nossa era). Localiza-se na parte superior de um afluente do rio Motagua, no vale de Copán, em Honduras ocidental; é de clima tropical com abundante flora e fauna. No século VII, Copán alcançou seu máximo esplendor.

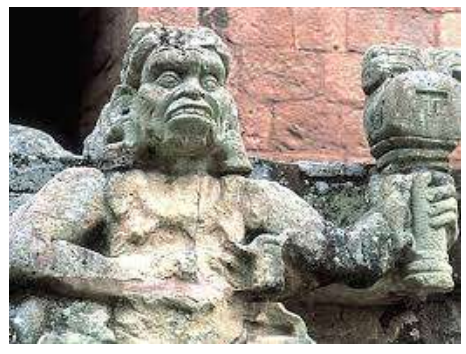

Dos primeiros governantes que ocuparam o trono de Copán não se sabe praticamente nada. Por volta do ano 700 d. C., se estabelece a tradição de não destruir os monumentos de seus predecessores; assim sua história pôde ser conhecida.

No final de 800 d. C. a cultura de Copán alcança seu apogeu: definem-se suas características escultóricas e arquitetônicas. As principais pirâmides-templo, bem como o "juego de pelota" (jogo de bola), se situam em uma acrópole artificial, que foi arrastada parcialmente pelo rio Copán. Muitas das estruturas continuam intactas. Talvez seu traço distintivo seja a quantidade e qualidade barroca dos monumentos lavrados em forma espiral, além das inscrições glíficas. 
No poema de Asturias, "Tiempo y muerte en Copán" (1975, p. 164), a cidade de Copán é a memória viva da civilização maia, registrada na contemporaneidade pelo verbo "ser" no tempo passado:

Otro fue, colores extraidos de la tierra, este pintar murales y tatuajes por horror a lo vano, tiempo y muerte: este encerrar en muros el espacio por horror al vacio, tiempo y muerte; este golpear la piedra y la madera por horror al silencio, tiemро у тиеrte.

Observa-se na composição poética o vasto potencial psíquico da linguagem oral, que através da repetição dos versos imprime um ritmo interno ao poema, logrando uma coreografia lírica da memória maia. O poema é uma dança de vocábulos em língua espanhola que plasmam as imagens da cultura maia.

No primeiro verso surgem os "colores extraídos de la tierra" (v. 1), alusão ao barro ou às vegetações, que serviram para extrair a tinta da pintura das cerâmicas, dos teares, dos murais ou das tatuagens, enfim, da arte, na qual os maias expressavam suas ideias e suas emoções. Porém, essas expressões artísticas plasmam o "horror a lo vano" (v. 3) que fazia parte do imaginário pré-hispânico: o povo maia, sob a dominação de imperadores e sacerdotes, construiu templos e pirâmides, que são verdadeiras obras de arte. Asturias, no poema, sintetiza esse "horror a lo vano" em uma poderosa anáfora, apoiada nos vocábulos "tiempo y muerte", tempo cíclico que, simultaneamente, traz a vida e a morte, pois os maias para sobreviver tiveram que trabalhar em muitas construções, sob o signo dos deuses. 
O poema simboliza o antagonismo entre vida e morte. Por meio de Copán, Asturias (1975, p. 164) desenvolve uma linguagem poética, que aborda a cidade de outrora e o horror a tudo. Ao final do poema, esse horror se revela como temor à morte:

Otro fue, en amoroso musgo los sentidos, este yacer en cáscara de hembra por horror a secarse, tiempo y muerte; este lanzar las flechas de la vida por horror a guardarlas, tiempo y muerte; y este quedar en hijos de la carne, por horror a la huesa, tiempo y muerte.

A oposição entre os valores efêmeros, como o tempo, e os eternos, como a morte, propicia um jogo de linguagem inerente ao barroco, quando se opunham os valores terrenos e celestiais. No poema "Tiempo y muerte en Copán" (1975, p. 164-165), essa oposição não possui a conotação da Fé cristã, e sim as concepções religiosas contidas no Popol-Vuh como, por exemplo, nos seguintes versos:

este adorar la lluvia, el sol, la tierra,

este herirse la lengua con espinas

y este aprender los nombres del camino

este lanzar las flechas de la vida.

A cidade de Copán, em Honduras, representa a morte da civilização maia e, ao mesmo tempo, a presença viva dessa civilização, através do legado que deixou: costumes, crenças e linguagem. A linguagem - registro de sua história no papel dos

Revista Texto Poético | ISSN: 1808-5385 | Vol. 18 (10 sem-2015) - p. 26 
livros ou na pedra dos templos, portais e baixos-relevos, além das pirâmides, estelas e esculturas - é testemunho do apogeu da cultura maia.

\section{II}

O segundo poeta a ser abordado, Octavio Paz (Prêmio Nobel de Literatura em 1990), apresenta uma vasta produção poética, na qual se distinguem dois traços preponderantes, o ocidental e o oriental. Este estudo seguirá o olhar de Paz em direção às raízes précolombianas do México.

Para entender melhor a obra do escritor mexicano, é necessário conhecer as civilizações anteriores à chegada dos espanhóis na América. Não só se trata da memória do poeta, mas também da memória de um povo. De acordo com Paz (1992, p. 22), "a poesia brota de um fundo psíquico que se confunde com a linguagem mesmo, isto é, com a memória de um povo e de uma cultura”. Elementos da cultura asteca, como os deuses Tláloc, Coatlicue, Xochipilli e o calendário sagrado, fazem parte de Lección de cosas, e se juntam a outros elementos da cultura maia, que compõem "En Uxmal” e integram Piedras sueltas (1955).

Quanto ao poema "Piedra de sol" (1957), de Libertad bajo palabra, caracteriza-se por representar o calendário asteca, que expressa um aspecto básico da filosofia nahua ${ }^{7}$, simbolizado pelo reencontro dinâmico de duas serpentes, as quais formam o contorno da pedra circular e representam não a dualidade trevas-luz, mortevida, e sim a harmonia entre esses elementos aparentemente opostos. No centro do calendário está o Quinto $\mathrm{Sol}^{8}$, que significa 
movimento, portanto, o eixo que impulsiona o processo cíclico do tempo e da concepção filosófica dos astecas.

Octavio Paz (1990, p. 794), apoiado no pensamento dos nahuas, criou o poema "Piedra de sol" com 584 endecassílabos, número de versos igual ao da revolução sinódica do planeta Vênus, que é de 584 dias. A primeira e a última estrofes foram compostas iguais, revelando, como a filosofia asteca, o caráter cíclico do poema. Também os dois signos mexicas, movimento e vento ${ }^{9}$, figuram nessas estrofes. $\mathrm{O}$ movimento se expressa pelos seguintes vocábulos: "arquea", “danzante”, "caminar", "curva", “avanza”, "retrocede" e "llega". E o vento se encontra registrado no segundo verso dessa estrofe.

O poema "Piedra de sol" trata do ato de criação poética, "un caminar tranquilo", "ola tras ola", que em constante movimento traz a imaginação e se torna "unánime presencia en el oleaje" como se a pedra do sol estivesse girando, porque sua circularidade e seus signos gravados assim o denotam. Girando em busca do passado primordial, um passado criador, que ao ser rememorado se desfaz (PAZ, 1990, p. 262):

corredores sin fin de la memoria, puertas abiertas a un salón vacio donde se pudren todos los veranos, las joyas de la sed arden al fondo, rostro desvanecido al recordarlo, mano que se deshace si la toco, cabelleras de arañas en tumulto sobre sonrisas de hace muchos años

Nesse poema, deve-se destacar a apresentação da natureza, que algumas vezes surge como imagem (luz, vegetação, rio, corpo 
de mulher, rosto...), outras surge como som (canto), ou ainda como tato (dedos) e paladar (boca). Por meio dessas imagens poéticas, que envolvem os quatro sentidos, o eu lírico caminha não mais através da natureza, e sim pelo tempo (PAZ, 1990, p. 276):

el día es inmortal, asciende, crece, acaba de nacer y nunca acaba, cada día es nacer, un nacimiento es cada día amanecer y yo amanezco,

E chega à conclusão que "no hay nada frente a mí, sólo un instante" (PAZ, 1990, p. 264). Um instante que é o tempo petrificado ou petrificante da imaginação feita poesia:
el instante se abisma y se penetra, como un puño se cierra, como un fruto que madura hacia dentro de sí mismo y a si mismo se bebe y se derrama

O eu lírico, ao petrificar as imagens poéticas que fluíam em sua imaginação, reflete sobre $\mathrm{o}$ ato de criação literária imprimindo à linguagem poética um tom crítico (PAZ, 1990, p. 265):

el instante translúcido se cierra

y madura hacia dentro, echa raices, crece dentro de mí, me ocupa todo, me expulsa su follaje delirante, mis pensamientos sólo son sus pájaros

Ao expulsar a "follaje delirante", o instante realiza a crítica de si mesmo, afasta as folhas supérfluas e se despetrifica: "despetrificou-se o instante em outro e outro" (PAZ, 1990, p. 277). 
Desfaz-se e, como uma reação em cadeia, refaz-se análogo ao espelho mágico do tempo:

dormí sueños de piedra que no sueña

y al cabo de los años como piedras

oi cantar mi sangre encarcelada

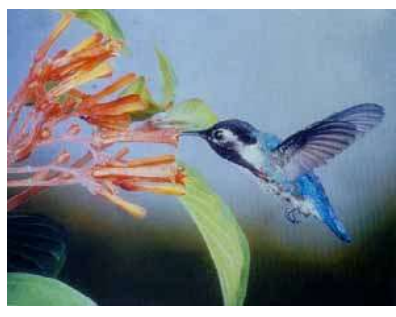

Octavio Paz, em sua composição poética "La exclamación" (1990, p. 435), que faz parte de Ladera Este e aborda a imagem do beija-flor ("colibrí"), compara o beija-flor a um poema e revela a instantaneidade do tempo: "É capaz de voar verticalmente, horizontalmente e inclusive de manter-se suspenso no ar. Quando vejo um beija-flor, digo: é uma exclamação, como um pequeno poema" (PAZ, 1990, p.101).

\author{
LA EXCLAMACIÓN \\ QUIETO \\ no en la rama \\ en el aire \\ No en el aire \\ en el instante \\ el colibri
}

De acordo com Paz, ao receber o "Premio de Literatura en Lengua Castellana 'Miguel de Cervantes' 1981", “em Pedra de sol, a vida humana é um processo feito de anos e dias em volta de um ponto, um instante no qual ardem e se apagam, aparecem e desaparecem todos os tempos, todos os instantes" (PAZ, p. 1990). 
Octavio Paz, depois de anos no exterior, regressa ao México, em 1968, e escreve "Vuelta", inclinando-se ainda mais sobre suas raízes. Busca, na memória, outro tempo que já não existe (PAZ, 1990, p. 598):

\author{
Camino hacia atrás \\ hacia lo que dejé \\ o me dejó \\ Memoria \\ inminencia de precipicio \\ balcón \\ sobre el vacio
}

Trata-se, aparentemente, de um poema de contrastes, comparação entre passado e presente, em que as águias e os jaguares da cultura asteca são substituídos pela pistola e pelo machado (PAZ, 1990, p. 599):

\author{
En esquinas y plazas \\ sobre anchos zócalos de lugares comunes \\ los Padres de la Iglesia cívica \\ cónclave taciturno de Gigantes y Cabezudos \\ ni águilas ni jaguares \\ [...] \\ los altares al máuser y al machete
}

Entretanto, o jogo dialético da linguagem paciana revela o desencanto do sujeito do poema em relação a Mixcoac, o eu lírico volta-se para a pequena praça, metáfora do centro de si mesmo (PAZ, 1990, p. 601):

Todo es ganancia

si todo es pérdida 
Camino hacia mí mismo

hacia la plazuela

Porque, para o sujeito lírico, não existe um só tempo, há uma superposição temporal, um tempo infinito e instantâneo no qual tudo é presença (PAZ, 1990, p. 601):

\author{
El espacio está adentro \\ no es un edén subvertido \\ es un latido de tiempo \\ Los lugares son confluencias \\ aleteo de presencias \\ en un espacio instantáneo
}

Na concepção de Paz (1991, p. 56), “a memória, ao ressuscitar o passado, o modifica, o recria e, assim, o torna presente, presença".

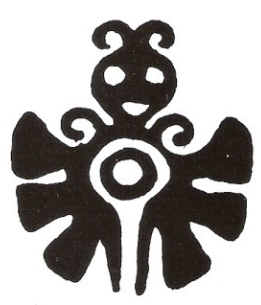

Octavio Paz, ao buscar suas raízes mexicanas, também encontra a "mariposa de obsidiana" ${ }^{10}$,Itzpapálotl (itzli, obsidiana; papálotl, mariposa), representante do amor, deusa das flores e da vegetação na cultura asteca. Sua mobilidade fez com que esse povo a tomasse como símbolo do movimento, pois indica os movimentos do sol e também representa os deuses do caminho. Na composição poética paciana, "Mariposa de obsidiana", nome do inseto sagrado dos astecas e faz parte de ¿Aguila o sol? (1949-1950), a mariposa sente-se solitária: "Estoy sola y caída, grano de maíz desprendido de la mazorca del tiempo" (PAZ, 1990, p. 214-216). Necessita voltar à unidade e, com esse fim, dirige-se a um tu: "Siémbrame entre los fusilados. [...]. Mi cuerpo arado por el tuyo ha de volverse un campo donde se siembra uno y se cosecha ciento" (PAZ, 1990, p. 214- 
216).Trata-se de um corpo social, que representa o povo nahua e que se desdobra em corpo erótico, pois o eu lírico, ao se valer da sedução da linguagem, ingressa em um jogo erótico: "Toca mis pechos de yerba. Besa mi vientre, piedra de sacrifícios" (PAZ, 1990, p. 214216). Em um pacto de vida-morte, a mariposa traz à memória desse tu coletivo as imagens que ele deve beber e recordar: "De mi cuerpo brotan imágenes: bebe en esas aguas y recuerda lo que olvidaste al nacer"(PAZ, 1990, p. 214-216). O corpo imagístico da mariposa reflete a memória do povo asteca e, simultaneamente, reivindica a recordação viva do passado, já que o inseto divino é "la herida que no cicatriza" (PAZ, 1990, p. 214-216).

$\mathrm{Na}$ composição poética paciana (1990, p. 214-216), a mariposa, como sujeito do discurso, identifica-se inicialmente por seu tamanho ("Me hice tan pequeña") e por sua localização às margens do lago Texcoco:

Mataron a mis hermanos, a mis hijos, a mis tios. A la orilla del lago de Texcoco me eché a llorar. [...]. Me cogieron suavemente y me depositaron en el atrio de la Catedral. Me hice tan pequeña y tan gris que muchos me confundieron con un montoncito de polvo.

Esse sujeto está, mais adiante, ratificado pela própria mariposa: "Sí, yo misma, la madre del pedernal y de la estrella, yo, encinta del rayo, soy ahora pluma azul que abandona el pájaro en la zarza". A expressão "madre del pedernal" denota o caráter de sacrifício com o qual se reveste a mariposa. O pedernal era o punhal de sacrifício dos astecas.

No texto de Octavio Paz, a mariposa conota algumas vezes o apogeu e em outras a decadência da civilização asteca. Entre 
passado e presente, no jogo dialético da linguagem, as flutuações simbólicas da mariposa realizam um sistema de analogias, sintetizado na projeção de um futuro. Por meio da linguagem, de acordo com Maria Lúcia Aranha (1986, p. 28): “[...] não necessitamos mais da existência física das coisas: criamos [...] um mundo estável de ideias que nos permite recordar o que já foi e projetar o que será. [...] Pela linguagem, o homem deixa de reagir somente ao presente, ao imediato; passa a poder pensar o passado e o futuro $[\ldots]$.

A mariposa, ao atravessar passado, presente e futuro, eterniza-se como memória da cultura asteca e se revela, na estrutura do poema de Paz (1990, p. 214-216), como "el centro fijo que mueve la danza" semelhante aos "voadores"11 da cultura olmeca, os quais representam os cinco ventos ${ }^{12}$, ou seja, os quatro pontos cardeais mais um, central, que impulsiona os outros. Esse movimento cósmico está bem assinalado, na produção paciana, por meio do verbo girar, que pela repetição e pelo tempo em que está empregado (gerundio) imprime um movimento contínuo: "Bailaba, los pechos en alto y girando, girando, girando hasta quedarme quieta; entonces empezaba a echar hojas, flores, frutos" (1990, p. 215). O poeta, ao imprimir significado à dança da mariposa, logra uma analogia com a linguagem coreográfica do inseto com o ritmo interno da criação literária. Os voos da mariposa se aproximam aos da imaginação.

A localização do espaço, no poema, é fundamental, não só pela identificação do lago Texcoco da época dos nahuas mas também pela função referencial que exerce esse lago: assinalar o contexto mítico e histórico, no qual se desenvolve a composição poética paciana. A cidade de Tenochtitlan, capital do império asteca, de acordo com a lenda, deveria ser fundada em uma ilha, no centro 
de um lago, onde tivesse um cactus (nopal), uma serpente e una águia. Texcoco simboliza o centro do universo e, no poema de Paz, o ponto onde convergem todos os olhares, principalmente os dos leitores. Octavio Paz, por meio da voz da mariposa, se apoia nesse centro de convergências para denunciar a matança de um povo. $\mathrm{O}$ emprego dos verbos no pretérito imperfeito reforça, na composição poética (1990, p. 215), a ideia de um pasado inconcluso - a devoração de uma civilização - e a impotência da mariposa perante a realidade:

En otros tiempos cada hora nacía del vaho de mi aliento, bailaba un instante sobre la punta de mi puñal y desaparecía por la puerta resplandeciente de mi espejito. [...]. Me bañaba en la cascada solar, me bañaba en mí misma, anegada en mi propio resplandor. [...]

O inseto sagrado dos astecas está cansado de ser objeto de olhares, e como a criação poética prefere devorar-se a si mesmo, ser sujeito de seu próprio olhar (1990, p. 216):

Estoy cansada de tantas cuentas de piedras desparramadas en el polvo. Estoy cansada de este solitario trunco. Dichoso el alacrán madre, que devora a sus hijos. [...]. Dichosa el agua que se bebe a si misma. ¿Cuándo acabarán de devorarme estas imágenes? ¿Cuándo acabaré de caer en esos ojos desiertos?

O apelo de solidariedade em busca de um novo tempo instaura a ideia de renascimento: "Toma mi collar de lágrimas. Te espero en ese lado del tiempo en donde la luz inaugura un reinado dichoso: el pacto de los gemelos enemigos, el agua que escapa entre los dedos y el hielo, petrificado como un rey en su orgullo" (PAZ, 
1990, p. 214-216). A mariposa, como um grande livro aberto, que narra a história de seu povo, se coloca à disposição de um $t u$ coletivo, metáfora da humanidade: "Allí abrirás mi cuerpo en dos, para leer las letras de tu destino". Deste modo, o inseto sagrado dos astecas, ao recordar aos homens o passado de trevas, propicia a reconstrução de um futuro de luz.

\section{Referências}

\section{Referências do Capítulo I}

ASTURIAS, Miguel Ángel. Clarivigilia primaveral. Buenos Aires: Losada, 1965.

. Leyendas de Guatemala. 2. ed. Madrid: Alianza, 1985.

. La novela latinoamericana, testimonio de una época. Miguel Ángel Asturias, The Nobel Prize in Literature 1967. The Nobel Foundation, Stockolm. In:

http://www.nobelprize.org/nobel_prizes/literature/laureates/1967/asturias19 68

. Poesía. Obras completas. 3. ed. Madrid: Aguilar, 1968, 3v.

. Los ojos de los enterrados. Madrid: Alianza, 1982.

. El Papa Verde. Madrid: Alianza, 1982.

. Viento fuerte. Buenos Aires: Losada, 1976.

. Los poetas. Miguel Angel Asturias. Estudio y selección Carlos

Meneses. Madrid: Júcar, 1975.

ASTURIAS, Miguel Ángel. In: COUFFON, Claude. Miguel Ángel Asturias y el realismo mágico. In: Alcor, marzo-junio, 1963. 
ASTURIAS, Miguel Ángel. In: LORENZ, Günter W. Diálogo com a América Latina: panorama de uma literatura do futuro. Trad. Rosemary Costhek Abílio y Fredy de Souza Rodrigues. São Paulo: EPU, 1973.

ASTURIAS, Miguel Ángel. In: LÓPEZ ÁLVAREZ, L. Conversaciones con Miguel Ángel Asturias. Madrid: Magisterio Español, 1974.

ASTURIAS, M. A.; GONZÁLEZ DE MENDOZA, J. M. Popol-Vuh o Libro del Consejo de los Indios Quichés. Buenos Aires: Losada, 1983.

\section{Referências do Capítulo II}

PAZ, Octavio. Autopercepción intelectual de un proceso histórico. Anthropos. Barcelona: Anthropos, $\mathrm{n}^{0}$ 14, 1992, p.13-24.

. La casa de la presencia. Insula. Revista de Letras y Ciencias Humanas, 532-533 abril-mayo 1991. [Monográfico extraordinario dedicado al Premio Nobel de Literatura 1990].

. El laberinto de la soledad. 3. ed. México: Fondo de Cultura Económica, 1987.

. Los hijos del limo. Del romanticismo a la vanguardia. 2. ed. Barcelona: Seix Barral, 1989.

. Lectura comentada de poemas. El águila y el viento. Homenaje a Octavio Paz. Madrid: Comisión V Centenario; Murcia: Paraninfo, 1990.

. Obra poética (1935-1988). Barcelona: Seix Barral, 1990.

- "Premio de Literatura en Lengua Castellana "Miguel de Cervantes' 1981". Barcelona, Anthropos; Madrid: Ministerio de Cultura. Centro de las Letras Españolas, 1990.

. Las vaguardias cumplen cien años. Conferencia dictada en el Coloquio Las vanguardias cumplen 100 años. Barcelona: Museo Picasso, 13.06.1994. 


\section{Referências Gerais}

ARANHA, M. L. A.; MARTINS, M. H. P. Filosofando: introdução à filosofia. 2. ed. São Paulo: Moderna, 1993.

BAUMAN, Zygmunt. Ensaios sobre o conceito de cultura. Trad. Carlos Alberto Medeiros. Rio de Janeiro: Zahar, 2012.

. Legisladores e intérpretes. Rio de Janeiro: Jorge Zahar Ed., 2010. . Modernidade líquida. Trad. Plínio Dentzien. Rio de Janeiro: Jorge Zahar, 2001.

BENJAMIN, Walter. Obras escolhidas I: Magia e técnica, arte e politica. Trad. Sérgio Paulo Rouanet. São Paulo: Brasiliense, 1985.

BERMAN, Marshall. Tudo que é sólido desmancha no ar: a aventura da modernidade. Trad. Carlos Felipe Moisés; Ana Maria L. Ioriatti. 2. ed. São Paulo: Companhia das Letras, 1986.

BEUTELSPACHER, Carlos R. Las mariposas entre los antiguos mexicanos. México: Fondo de Cultura Económica, 1989.

BRETON, André. Manifestos do surrealismo. Trad. Luiz Forbes. São Paulo: Brasiliense, 1985.

CANTON, Katia. Tempo e memória. São Paulo: Martins Fontes, 2009.

DURAND, Gilbert. O imaginário: ensaio acerca das ciências e da filosofia da imagem. Trad. Renée Eve Levié. Rio de Janeiro: DIFEL, 1998.

GUBERMAN, Mariluci. Miguel Angel Asturias e sua poesia: do cenário mágico à linguagemcoreográfica de imagens. In: GUBERMAN, Mariluci (Org.). Poesia Hispano-Americana: imagem, imagem, imagem... Rio de Janeiro: Programa de Pós-Graduação em Letras Neolatinas UFRJ; Brasília: CAPES, 2006, p.125-134. 
. A morte das vanguardas. Jornal do Brasil. Ideias/Livros. Rio de Janeiro, 02/07/1994, p. 5.

. Octavio Paz e a estética de transfiguração da presença. Rio de Janeiro: UFRJ; SEPEHA, Seminário Permanente de Estudos HispanoAmericanos, 1997. Em Espanhol: - Octavio Paz y la estética de transfiguración de la presencia. Valladolid (España): Universitas Castellae, 1998.

- Poesia e Revolução na América Hispânica. Rio de Janeiro: UFRJ, Programa de Pós-Graduação em Letras Neolatinas; Brasília: CAPES, PRODOC, 2009.

LEÓN-PORTILLA, Miguel. Tiempo y realidad en el pensamiento maya. México: UNAM, Instituto de Investigaciones Históricas, 1968.

THOMPSON, J. Eric S. Historia y religión de los mayas. 8. ed. México, España, Argentina, Colombia: Siglo XXI, 1987 (Colección América Nuestra).

VILLAFAÑE, Justo. Introducción a la teoría de la imagen. Madrid: Pirámide, 2002. 